\title{
Kajian aktivitas antibakteri, antioksidan, dan sitotoksik fungi endofit genus Fusarium sp. isolat daun meniran (Phyllantus niruri Linn.)
}

\author{
Rollando, Martanty Aditya, Dion Notario, Eva Monica, Rehmadanta Sitepu \\ Program Studi Farmasi, Fakultas Sains dan Teknologi, Universitas Ma Chung, Malang, \\ Villa Puncak Tidar N-01, Malang 65151
}

Submitted: 17-01-2017

Reviewed: 27-03-2017

Accepted: 12-04-2017

\begin{abstract}
ABSTRAK
Fungi endofit dimanfaatkan sebagai sumber daya baru untuk menghasilkan senyawa bioaktif seperti antibakteri, antioksidan dan antikanker. Penelitian ini bertujuan menganalisis daya antibakteri, antioksidan, sitotoksik fraksi hasil pemisahan ekstrak etil asetat dari miselium fungi endofit genus Fusarium $s p$. Fraksi dietil eter menunjukan aktivitas antibakteri yang tinggi dengan nilai $\mathrm{IC}_{50}$ pada bakteri E.coli $(20,75 \mu \mathrm{g} / \mathrm{mL})$, S.typhi $(35,08 \mu \mathrm{g} / \mathrm{mL})$, dan S.aureus $(51,96 \mu \mathrm{g} / \mathrm{mL})$. Uji aktivitas antioksidan menunjukan bahwa fraksi etanol $96 \%$ mempunyai aktivitas antioksidan dan kandungan fenolik total yang paling tinggi $(75,85 \pm 0,11 \mathrm{mg}$ GAE). Uji sitotoksik pada sel kanker payudara jenis T47D menunjukan fraksi dietil eter mempunyai aktivitas tertinggi dengan $\mathrm{IC}_{50}$ sebesar $10,16 \pm 0,88$ $\mu \mathrm{g} / \mathrm{mL}$ dibandingkan fraksi $\mathrm{n}$-heksan dan etanol.
\end{abstract}

Kata kunci: antibakteri, antioksidan, fungi endofit, kandungan fenolat total, sitotoksisitas

\begin{abstract}
Endophytic fungi used as a new resource to produce bioactive compounds such as antibacterial, antioxidant and anticancer. This study aimed to analyze the antibacterial, antioxidant, cytotoxic fraction from separation ethyl acetate extract of mycelium of endophytic fungi genus Fusarium sp. Diethyl ether fraction showed high antibacterial activity in E.coli $(20.75 \mu \mathrm{g} / \mathrm{mL})$, S.typhi $(35.08$ $\mu \mathrm{g} / \mathrm{mL})$, and S.aureus $(51.96 \mu \mathrm{g} / \mathrm{mL})$. Test showed that the antioxidant activity of ethanol $96 \%$ fraction has highest antioxidant activity and total phenolic content (75.85 $\pm 0.87 \mathrm{mg} \mathrm{GAE})$. Cytotoxic test on T47D breast cancer cells showed that the fraction of diethyl ether have highest activity with $\mathrm{IC}_{50}$ of $10.16 \pm 0.88 \mu \mathrm{g} / \mathrm{mL}$ compared to $\mathrm{n}$-hexane and ethanol fraction.
\end{abstract}

Keywords: antibacterial, antioxidant, cytotoxic, endhophyte, total phenolic.

\footnotetext{
Penulis Korespondensi:

Rollando

Program Studi Farmasi, Fakultas Sains dan Teknologi, Universitas Ma Chung, Malang

Villa Puncak Tidar N-01, Malang 65151

Email: ro.llando@machung.ac.id
} 


\section{PENDAHULUAN}

Indonesia adalah negara tropis yang kaya akan plasma nutfah tidak ternilai. Menurut Dewoto (2007), Indonesia memiliki lebih kurang 30.000 spesies tumbuhan dan 940 spesies merupakan tumbuhan berkhasiat obat yang dapat dijadikan sumber isolat jamur endofit. Salah satu tumbuhan berkhasiat obat yang memiliki banyak manfaat adalah tumbuhan meniran (Phyllantus niruri Linn.). Colpo et al., (2014) menyatakan bahwa tumbuhan meniran dapat digunakan sebagai obat infeksi saluran kemih, imonomodulator, antiinflamasi, dan antiviral. Tanaman ini mengandung senyawasenyawa yang berkhasiat antara lain lignan, glikosida, alkaloid, elagitanin, terpen dan fenilpropanoid, flavonoid dan polifenol, seperti kuersetin.

Mikroba endofit adalah organisme hidup yang berukuran mikro (bakteri dan fungi) yang hidup di dalam jaringan tanaman (xylem dan phloem), daun, akar, buah, dan batang (Strobel, 2003). Fungi endofit menghasilkan berbagai senyawa yang memiliki aktivitas biologi, antara lain alkaloid, terpenoid, fenolik, dan sebagainya (Tan dan Zou, 2001). Fungi endofit dapat menghasilkan senyawasenyawa bioaktif misalnya senyawa antioksidan, antikanker, antibakteri, antivirus, antifungi, antimalaria dan sebagainya (Kharwar et al., 2009). Penelitian ini diharapkan dapat memperjelas dan memberikan informasi ilmiah tentang aktivitas fraksi n-heksan, dieteil eter, dan etanol dari ekstrak etil asetat yang diambil dari sel fungi endofit genus Fusarium sp. yang diisolasi dari daun meniran (Phyllantus niruri Linn.) sebagai antioksidan, antibakteri, dan sitotoksik secara in vitro.

\section{METODE PENELITIAN Alat dan Bahan}

Alat yang digunakan yaitu vial, tabung ependorf, otoklaf (AC-300AE, Tiyoda Manufacturing Co. Ltd.), kotak aseptis, cawan petri, Öse, plug, shaking incubator, paper disc, microtiter plate 96well, mikropipet, inkubator (Sakura, Jepang), oven, dan alat gelas, neraca analitik (BP221S, Scaltec SBC 22, BP 160P), Laminar Air Flow cabinet (FARRco), vortex (junke \& kunkel), spektrofotometer UV-VIS, vacuum rotary evaporator (Junke dan Kunkel), waterbath (labo-tech, Heraceus), shakker. Bahan utama yang digunakan adalah fungi endofit genus Fusarium sp. yang telah diisolasi dari daun meniran, Muller Hinton, PDB (Potato Dextrose Broth), PDA (Potato Dextrose Agar), NA (Nutrient Agar), dan NB (Nutrient Broth). Mikroba uji Escherichia coli ATCC 25922, Staphylococcus aureus ATCC 15433, Salmonella thypi ATCC 23452, dan kontrol positif streptomisin. Lempeng silica gel $\mathrm{F}_{254}$ (E.Merck, Jerman), dan silika gel 60 untuk kromatografi kolom. Asam galat, vitamin C, pelarut ekstraksi etil asetat kalium ferisianid, E. Merck, Darmstat, Jerman), dan fase gerak untuk pemisahan dan pemurnian air suling metanol, n-heksana, kloroform. Pelarut fraksinasi n-heksana, dietil eter, dan etanol. Hidrogen peroksida, dapar, fosfat, potassium, ferisianida, $\mathrm{FeCl}_{3}$. Kultur sel T47D ditumbuhkan pada media kultur DMEM high glucose (Dulbecco's Modified Eagle Media) (Gibco) yang mengandung Fetal Bovine Serum (FBS) 10\% (v/v) (FBS Qualified, Gibco, Invitrogen USA), penisilinstreptomisin 1,5\% (v/v) (Gibco, Invitrogen USA dan Fungizone 0,5\% v/v (Gibco). Tissue Culture Dish (IWAKI brand), tripsin-EDTA 0,25\% (Gibco, Invitrogen Canada).

\section{Jalannya penelitian}

\section{Pengembangbiakan fungi endofit dan preparasi sampel}

Produksi fungi endofit dilakukan dengan cara menumbuhkan fungi endofit dalam media PDB. Diambil koloni fungi endofit genus Fusarium sp. dari media PDA dengan menggunakan Öse sebanyak 5 plug berdiameter $0,5 \mathrm{~cm}$ yang telah dicetak dengan pelubang. Koloni tersebut diinokulasikan ke dalam $200 \mathrm{~mL}$ media PDB yang telah disterilkan pada labu Erlenmeyer $500 \mathrm{~mL}$ dan diinkubasi pada rotary shaker dengan kecepatan putaran $1000 \mathrm{rpm}$, suhu ruangan selama 14 hari. Miselium dan filtrat dipisahkan dengan cara disaring. Miselium dikeringkan pada suhu $50{ }^{\circ} \mathrm{C}$,-kemudian diserbuk.

\section{Ekstraksi}

Metode ekstraksi yang digunakan adalah metode maserasi menggunakan pelarut etil asetat. Serbuk miselium direndam dalam etil asetat (1:3) selama 48 jam dengan mengaduk sesering mungkin. 
Selanjutnya filtrat etil asetat dipisahkan dari residunya dengan cara penyaringan. Residu yang diperoleh kemudian direndam lagi dengan etil asetat selama 24 jam sambil diaduk sesering mungkin. Setelah 24 jam dilakukan penyaringan untuk memperoleh filtrat etil asetat. Filtrat hasil ekstraksi pada 48 dan 24 jam diuapkan dengan rotary evaporator pada suhu $\pm 40{ }^{\circ} \mathrm{C}$ sehingga diperoleh ekstrak pekat (Kharwar et al., 2009).

\section{Fraksinasi ekstrak}

Ekstrak pekat etil asetat difraksinasi dengan n-heksana, dietil eter dan etanol $96 \%$ secara berurutan dengan menggunakan kromatografi kolom. $200 \mathrm{mg}$ ekstrak kental dilarutkan dengan $50 \mathrm{ml}$ etil asetat, kemudian dimasukan kedalam kolom kromatografi $(30 \times 1.5 \mathrm{~cm})$ yang telah diisi dengan silika. Dimasukkan ke dalam kolom $200 \mathrm{ml}$-heksana, cairan yang keluar ditampung ke dalam botol. Penampungan cairan n-heksana dihentikan ketika cairan n-heksana yang keluar dari kolom sudah terlihat bening. Fraksinasi menggunakan dietil eter dan etanol $96 \%$ juga dilakukan dengan cara yang sama seperti fraksinasi menggunakan n-heksana. Fraksi n-heksana, dietil eter, dan etanol $96 \%$ diuapkan dengan rotary evaporator pada suhu $\pm 40{ }^{\circ} \mathrm{C}$ untuk memperoleh ekstrak kental n-heksana, dietil eter, dan etanol $96 \%$. Semua fraksi pekat n-heksana, dietil eter, dan etanol $96 \%$ dikeringkan pada suhu $\pm 50{ }^{\circ} \mathrm{C}$ menggunakan oven.

\section{Skrining fraksi aktif}

Pengujian aktivitas antimikroba dilakukan dengan metode disc diffusion (Kirby-Bauer Test). Mikroba uji yang digunakan E.coli, S.aureus, dan S.thypi. Dibuat seri konsentrasi fraksi uji 100; 50; $25 ; 12,5$; dan $6,25 \mu \mathrm{g} / \mu \mathrm{L}$ menggunakan DMSO $0.2 \%$. Sebanyak $10 \mu \mathrm{L}$ senyawa uji dengan lima konsentrasi tersebut diteteskan pada paper disc sehingga jumlah ekstrak pada setiap paper disc berturut-turut adalah $1000 ; 500 ; 250 ; 125$; dan $62,5 \mu \mathrm{g}$. Sebelum ditempelkan pada media berisi bakteri uji, paper disc yang berisi senyawa analit ditunggu sampai kering, yang menandakan pelarutnya sudah menguap. Digunakan kontrol positif $10 \mu \mathrm{L}$ streptomisin $10 \mathrm{mg} / \mathrm{mL}$ dan kontrol pelarut $10 \mu \mathrm{L}$ etanol absolut steril (harus diuapkan). Kultur bakteri uji diinkubasi pada suhu $37{ }^{\circ} \mathrm{C}$ selama 18-24 jam, diamati zona hambatan di sekeliling paper disc dengan mengukur diameter zona hambat, dan diperoleh fraksi aktif (Hudziki, 2009).

\section{Penentuan $\mathrm{IC}_{50}$ dan Kadar Bunuh Minimum (KBM) fraksi}

Kadar Bunuh Minimum ditentukan dengan metode mikrodilusi. Ke dalam sumur microtiter plate 96-well dimasukkan $50 \mu \mathrm{L}$ media Muller Hinton, $50 \mu \mathrm{L}$ suspensi mikroba uji yang telah disesuaikan kekeruhannya dengan standar McFarland 0,5 dan diencerkan (1:10) dan $100 \mu \mathrm{L}$ fraksi aktif dengan seri konsentrasi $500 ; 250 ; 125 ; 62,5 ; 31,25 ; 15,63 ; 7,81$; dan $3,91 \mu \mathrm{g} / \mathrm{mL}$ sehingga konsentrasi akhir larutan adalah $250 ; 125 ; 62,5 ; 31,25 ; 15,63 ; 7,81 ; 3,91$; dan $1,96 \mu \mathrm{g} / \mathrm{mL}$. Sebagai kontrol negatif dimasukkan ke sumuran dengan mencampurkan $100 \mu \mathrm{L}$ fraksi setiap konsentrasi dan $100 \mu \mathrm{L}$ media tanpa bakteri, kontrol bakteri uji digunakan sebanyak $50 \mu \mathrm{L}$ bakteri uji dan $150 \mu \mathrm{L}$ media, dan kontrol positif digunakan larutan streptomisin $10 \mathrm{mg} / \mathrm{mL}$ sebanyak $100 \mu \mathrm{L}$, bakteri uji sebanyak $50 \mu \mathrm{L}$, dan $50 \mu \mathrm{L}$ media.

Pengamatan dilakukan setelah inkubasi pada suhu $37{ }^{\circ} \mathrm{C}$ selama $18-24$ jam. Densitas sel diukur menggunakan instrumen microplate reader dengan mengamati absorbansi pada panjang gelombang $595 \mathrm{~nm}$. Selanjutnya absorbansi suspensi sel bakteri uji yang telah diberi perlakuan larutan uji dibandingkan dengan absorbansi suspensi sel bakteri tanpa perlakuan uji (kontrol). Nilai $\mathrm{IC}_{50}$ didapatkan dengan membuat grafik antara kadar isolat (absis) dengan persen penghambatan pertumbuhan bakteri uji (ordinat) dan dianalisis menggunakan metode Litchfield dan Wilcoxon (analisis probit) (Zellagui et al., 2012).

Penentuan nilai KBM dilakukan dengan mengambil cairan dari tiap microtiter plate 96-well sebanyak $3 \mu \mathrm{L}$ lalu digoreskan pada media NA steril tanpa penambahan mikroba dan senyawa uji. Goresan pada media NA yang terlihat jernih setelah inkubasi ditetapkan sebagai nilai KBM. 


\section{Determinasi kandungan fenolat total dalam fraksi}

Kandungan fenolat total tiap fraksi diestimasi menggunakan reagen Folin-Ciocalteu dengan standar asam galat. Setiap fraksi dilarutkan dalam metanol $(2 \mathrm{mg} / \mathrm{mL})$ dan ditambah $500 \mu \mathrm{L}$ reagen Folin-Ciocalteu (50\%), kemudian ditambah $2 \mathrm{~mL} \mathrm{Na}_{2} \mathrm{CO}_{3} 20 \%$, dan ditambah air suling sampai volume akhir $5 \mathrm{~mL}$ (Javanmradi et al., 2003) . Campuran didiamkan pada suhu ruangan selama 20 menit, kemudian absorbansi diukur pada panjang gelombang $765 \mathrm{~nm}$. Prosedur yang sama juga dilakukan untuk larutan standar asam galat dalam metanol dengan konsentrasi 30, 45, 60, 75, 90 $\mu \mathrm{g} / \mathrm{mL}$. Kurva standar kalibrasi asam galat dibuat untuk menghitung persamaan garis regresi dan diperoleh persamaan : $y=0,0134 x+3,187$ dengan $R^{2}=0,9997$, yang dipergunakan untuk menghitung kadar total fenolik dalam setiap fraksi.

\section{Uji aktivitas antioksidan dengan metode peroksida}

Kemampuan fraksi untuk menangkap hidrogen peroksida dilakukan berdasarkan metode Kumaran dan Karunakaran (2007). Larutan hidrogen peroksida (40 $\mathrm{mmol} / \mathrm{L})$ dibuat dengan menggunakan dapar fosfat $(50 \mathrm{mmol} / \mathrm{L}, \mathrm{pH} 7,5)$. Absorbansi hidrogen peroksida diukur pada panjang gelombang $230 \mathrm{~nm}$ menggunakan spektrofotometer. Fraksi dilarutkan dalam air suling sehingga diperoleh konsentrasi $2 \mathrm{mg} / \mathrm{mL}$. Larutan kemudian ditambahkan hidrogen peroksida dan absorbansi diukur pada panjang gelombang $230 \mathrm{~nm}$ setelah 10 menit. Larutan kontrol dibuat dengan mencampur dapar fosfat tanpa penambahan hidrogen peroksida. Persentase kemampuan fraksi dalam menangkap hidrogen peroksida dihitung dengan menggunakan persamaan berikut:

Penangkapan $\mathrm{H}_{2} \mathrm{O}_{2}(\%)=[(\mathrm{Ai}-\mathrm{At}) / \mathrm{Ai}] \times 100$

Ai: Absorbansi kontrol, At: Absorbansi sampel

\section{Uji aktivitas antioksidan dengan penurunan reduksi}

Potensi reduksi setiap fraksi diukur menggunakan metode Oyaiju (1986). Setiap fraksi dan standar $(2 \mathrm{mg} / \mathrm{mL})$ dalam $1 \mathrm{~mL}$ air suling dicampur dengan dapar fosfat $(2,5 \mathrm{~mL}, 0,2 \mathrm{~mol} / \mathrm{L}, \mathrm{pH} 6,6)$ dan kalium ferisianida $(2,5 \mathrm{~mL}, 1 \% \mathrm{~b} / \mathrm{v})$. Selanjutnya disetrifugasi selama 10 menit pada $3000 \mathrm{rpm}$. Lapisan atas larutan diambil sebanyak $2,5 \mathrm{~mL} 1 \% \mathrm{~b} / \mathrm{v}$, kemudian dicampur dengan air suling $(2,5 \mathrm{~mL})$ dan $\mathrm{FeCl}_{3}(0,5 \mathrm{~mL}, 0,1 \% \mathrm{~b} / \mathrm{v})$. Absorbansi larutan diukur pada panjang gelombang $700 \mathrm{~nm}$ menggunakan spektrofotometer.

\section{Uji sitoktosik fraksi dengan metode MTT}

Uji sitotoksisitas menggunakan metode MTT. Sel kanker payudara T47D ditumbuhkan dengan media kultur RPMI, sel normal Vero dalam media kultur M199, masing-masing berisi FBS 10\%, penisilin-streptomisin $1 \%$, dan fungizon $0,5 \%$. Konsentrasi larutan uji yang digunakan adalah 7,81; 15,$62 ; 31,25 ; 62,5 ; 125 ; 250 ; 500 \mu \mathrm{g} / \mathrm{ml}$. Viabilitas sel ditentukan dengan absorbansi pada $\lambda 595$ $\mathrm{nm}$ menggunakan plate reader. Data absorbansi perlakuan dikonversi ke dalam persen viabilitas dan digunakan untuk menghitung $\mathrm{IC}_{50}$. Selectivity Index (SI) merupakan hasil bagi antara $\mathrm{IC}_{50}$ sel Vero dan $\mathrm{IC}_{50}$ sel T47D.

\section{HASIL DAN PEMBAHASAN}

\section{Pengembangbiakan fungi endofit dan preparasi sampel}

Fungi endofit genus Fusarium sp. hasil isolasi dari daun meniran (memiliki karakteristik yaitu koloni fungi berwarna putih (Gambar 1). Identifikasi morfologi fungi dilakukan di Laboratorium Mikologi Fakultas Pertanian Universitas Gadjah Mada. Genus Fusarium. memiliki ciri-ciri, yaitu: miselium yang memadat dan berbentuk seperti spiral, tersusun atas pigmen hifa yang berwarna gelap, dan memproduksi sklerotia dengan bentuk seragam. Ciri-ciri tersebut sesuai dengan yang dipaparkan oleh Sharma yang menunjukkan fungi genus Fusarium sp. (Sharma,1989). 


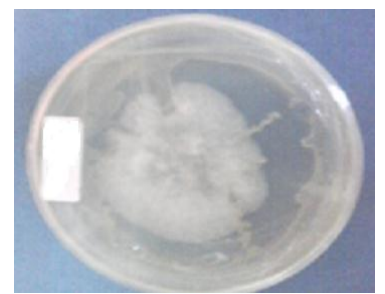

(a)

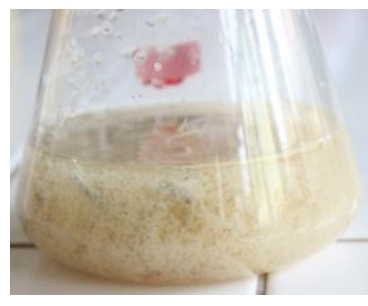

(b)

Gambar 1. (a). Morfologi Fusarium sp. umur 7 hari pada media natrium agar (NA). Perbesaran mikroskop 10X

(b). Kultur fungi Fusarium sp. hari ke-14 pada media potato dextrose broth (PDB)

\section{Penapisan fraksi aktif}

Fraksi dietil eter mempunyai aktivitas yang lebih baik dalam menghambat pertumbuhan bakteri uji dari pada fraksi n-heksana dan etanol 96\% (Tabel I). Fraksi n-heksana dan etanol 96\% menghambat pertumbuhan S.aureus, E.coli dan S.Thypi pada level konsentrasi tertinggi $(1000 \mu \mathrm{g})$. Fraksi dietil eter menunjukkan aktivitas menghambat pertumbuhan S.aureus, E.coli, dan S.thypi pada setiap konsentrasi uji.

Berdasarkan keseluruhan aktivitas penghambatan pertumbuhan bakteri uji, fraksi dietil eter mempunyai aktivitas yang lebih besar daripada fraksi n-heksana dan fraksi etanol 96\%, namun, berdasarkan tujuan penapisan aktivitas antibakteri, maka ketiga fraksi tersebut mempunyai potensi untuk dilakukan uji aktivitas (secara mikrodilusi). Fusarium sp. mempunyai senyawa aktif bikaverin yang terbukti dapat membunuh bakteri S.aureus, E.coli, p.aureginosa yang resisten terhadap antibiotik golongan penisilin (Deshmukh et al., 2014).

\section{Uji fraksi aktif}

Fraksi dietil eter lebih aktif dibandingkan fraksi n-heksana dan fraksi etanol $96 \%$ terhadap bakteri uji E.coli, S.aureus, dan S.typhi (Tabel II). Hal tersebut ditunjukkan dengan menganalisis nilai $\mathrm{IC}_{50}$. Misalnya dalam menghambat pertumbuhan bakteri S.thypi, fraksi dietil eter memerlukan konsentrasi $35,08 \mu \mathrm{g} / \mathrm{mL}$ dalam menghambat $50 \%$ pertumbuhan bakteri dibandingkan fraksi nheksana yang memerlukan konsentrasi lebih tinggi yaitu $134,11 \mu \mathrm{g} / \mathrm{mL}$.

Fraksi dietil eter mempunyai kemampuan membunuh bakteri atau nilai KBM lebih rendah dibandingkan fraksi n-heksana dan fraksi etanol $96 \%$ terhadap bakteri E.coli, S.aureus, dan S.typhi. Misalnya dalam membunuh bakteri S.aureus, fraksi dietil eter dapat membunuh $99,9 \%$ bakteri pada konsentrasi $125 \mu \mathrm{g} / \mathrm{mL}$, sedangkan fraksi etanol 96\%,-memerlukan dosis yang lebih tinggi dari 500 $\mu \mathrm{g} / \mathrm{mL}$.

\section{Analisis kandungan fenolik total}

Tabel III menunjukan kandungan fenolik total dengan rentang yang cukup lebar. Nilai bervariasi dari 12,87 - 75,85 mg GAE/g bobot kering fraksi. Kandungan tertinggi terdapat pada fraksi etanol 96\% (75,85 \pm 0,11 mg GAE), kemudian diikuti oleh fraksi dietil eter dan fraksi n-heksana. 
Tabel I. Hasil pengamatan uji disc diffusion fraksi terhadap bakteri uji

\begin{tabular}{|c|c|c|c|c|c|c|}
\hline \multirow[t]{2}{*}{ Fraksi } & \multirow{2}{*}{$\begin{array}{c}\text { Daya } \\
\text { tampung } \\
(\mu \mathrm{g})\end{array}$} & \multicolumn{5}{|c|}{ Zona Hambatan Pertumbuhan (mm) } \\
\hline & & S. aureus & E. coli & S. thypi & $\begin{array}{c}\text { Kontrol } \\
\text { Positif }\end{array}$ & $\begin{array}{l}\text { Kontrol } \\
\text { Negatif }\end{array}$ \\
\hline \multirow[t]{5}{*}{ n-heksanaa } & 62,5 & ND & ND & ND & \multirow{5}{*}{24} & \multirow{5}{*}{ ND } \\
\hline & 125 & ND & ND & ND & & \\
\hline & 250 & ND & ND & ND & & \\
\hline & 500 & ND & ND & 5 & & \\
\hline & 1000 & 8 & 9 & 3 & & \\
\hline \multirow[t]{5}{*}{ dietil eter } & 62,5 & 2 & ND & 1 & \multirow{5}{*}{22} & \multirow{5}{*}{ ND } \\
\hline & 125 & 3 & 5 & 2 & & \\
\hline & 250 & 6 & 6 & 8 & & \\
\hline & 500 & 8 & 10 & 9 & & \\
\hline & 1000 & 16 & 13 & 14 & & \\
\hline \multirow[t]{5}{*}{ etanol } & 62,5 & ND & ND & ND & \multirow{5}{*}{18} & \multirow{5}{*}{ ND } \\
\hline & 125 & ND & ND & ND & & \\
\hline & 250 & ND & ND & ND & & \\
\hline & 500 & ND & 2 & 7 & & \\
\hline & 1000 & 1 & 3 & 10 & & \\
\hline
\end{tabular}

Keterangan: ND $=$ not detected (tidak terdeteksi adanya aktivitas)

Tabel II. Nilai IC $_{50}$ dan nilai KBM setiap fraksi terhadap bakteri uji

\begin{tabular}{|c|c|c|c|c|c|c|}
\hline \multirow[t]{2}{*}{ BAKTERI } & \multicolumn{6}{|c|}{ SENYAWA } \\
\hline & $\begin{array}{c}\mathrm{IC}_{50} \\
(\mu \mathrm{g} / \mathrm{mL})\end{array}$ & $\begin{array}{c}\text { KBM } \\
(\mu \mathrm{g} / \mathrm{mL})\end{array}$ & $\begin{array}{c}\mathrm{IC}_{50} \\
(\mu \mathrm{g} / \mathrm{mL})\end{array}$ & $\begin{array}{c}\text { KBM } \\
(\mu \mathrm{g} / \mathrm{mL})\end{array}$ & $\begin{array}{c}\mathrm{IC}_{50} \\
(\mu \mathrm{g} / \mathrm{mL})\end{array}$ & $\begin{array}{c}\text { KBM } \\
(\mu \mathrm{g} / \mathrm{mL})\end{array}$ \\
\hline E.coli & 109,98 & $>500$ & 20,75 & 125 & 117,24 & $>500$ \\
\hline S.aureus & 265,46 & $>500$ & 51,96 & 250 & 102,64 & $>500$ \\
\hline S.typhi & 134,11 & $>500$ & 35,08 & 125 & 89,76 & $>500$ \\
\hline
\end{tabular}

Tabel III. Kandungan fenolik total fraksi

\begin{tabular}{cc}
\hline Fraksi & Kandungan Fenolik Total (mg GAE/g Fraksi) \\
\hline n-heksana & $12,87 \pm 0,96$ \\
dietil eter & $67,98 \pm 0,32$ \\
etanol $96 \%$ & $75,85 \pm 0,11$ \\
\hline
\end{tabular}

Uji aktivitas antioksidan dengan metode peroksida

Aktivitas potensial penangkapan reduksi hidrogen peroksida dari semua fraksi menunjukan rentang aktivitas $34-85 \%$ (Gambar 3). Aktivitas reduksi dari vitamin C yang digunakan sebagai kontrol positif sebesar 95\%. Fraksi etanol 95\% menunjukan aktivitas paling besar dari semua fraksi, yaitu sebesar $85 \%$ kemudian diikuti oleh fraksi dietil eter sebesar $76 \%$. 


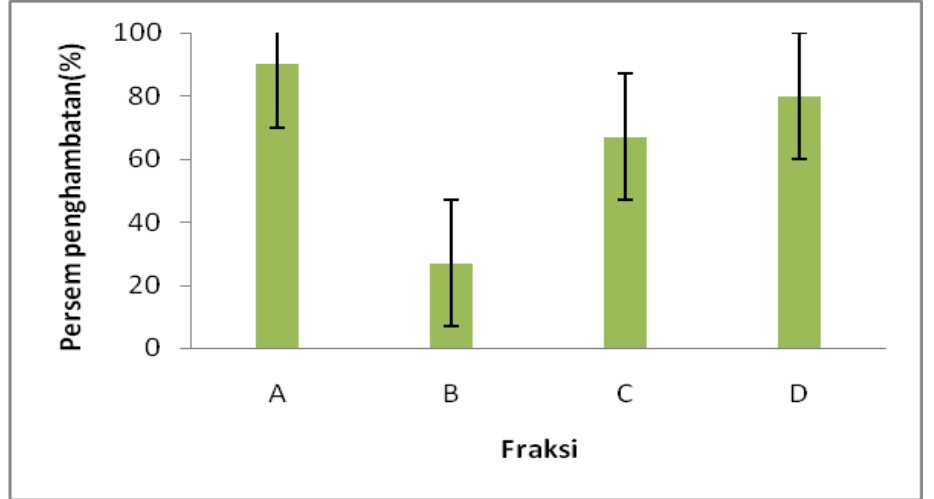

Gambar 2. Aktivitas penangkapan hidrogen peroksida A: Vitamin C, B: n-heksana, C: dietil eter, D: etanol $96 \%$

\section{Uji aktivitas antioksidan dengan metode penurunan reduksi.}

Kemampuan reduksi pada metode penurunan reduksi diukur dari perubahan ion $\mathrm{Fe}^{3+}$ menjadi $\mathrm{Fe}^{2+}$. Fraksi etanol $96 \%$ dan fraksi dietil eter menunjukan nilai absorbansi yang tinggi yang mengindikasikan potensi kemampuan yang besar dalam proses reduksi dan kemampuan mendonor elektron untuk menstabilkan radikal bebas. Aktivitas reduksi vitamin C sebesar $90 \%$ dan fraksi etanol 96\% mempunyai aktivitas penurunan reduksi terbesar yaitu $80 \%$ (Gambar 3).

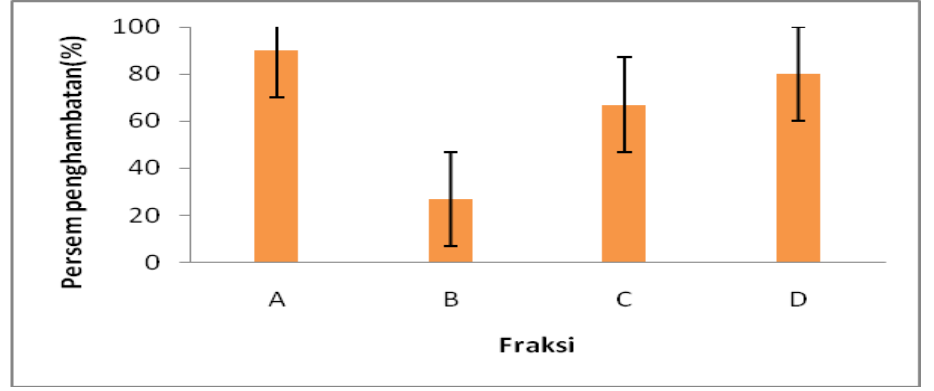

Gambar 3. Aktivitas kemampuan reduksi: A: Vitamin C, B: n-heksana, C: dietil eter, D: etanol 96\%

\section{Hubungan kandungan fenolik total dengan aktivitas antioksidan}

Uji aktivitas antioksidan menggunakan metode peroksida dan penurunan reduksi menunjukan hasil yang konsisten (Gambar 2 dan 3). Fraksi etanol mempunyai kandungan fenolik total terbesar dari semua fraksi $(65,70 \pm 0,87 \mathrm{mg}$ GAE). Fraksi etanol 96\% mempunyai aktivitas antioksidan terkuat di antara semua fraksi, kemudian diikuti oleh fraksi dietil eter dan n-heksana. Pelarut etanol merupakan pelarut yang polar dan dapat menarik senyawa polar seperti senyawa fenolik. Dari data tersebut menunjukan senyawa fenolik mempunyai peran dalam menurunkan aktifitas radikal bebas. Senyawa fenol mempunyai gugus hidroksi yang mempunyai peran utama dalam menangkap radikal bebas. Senyawa fenol dan terpen merupakan senyawa yang bertanggungjawab terhadap penurunan aktivitas peroksidasi lipid (Gulcin, 2006).

\section{Uji sitotoksik fraksi}

Berdasarkan parameter $\mathrm{IC}_{50}$, fraksi dietil eter mempunyai aktivitas sitotoksik lebih besar dibandingkan fraksi n-heksana dan etanol terhadap sel T47D (Tabel IV). Nilai IC $_{50}$ yang didapatkan pada perlakuan fraksi n-heksana, dietil eter dan etanol menunjukan bahwa semua fraksi memiliki potensi sebagai agen sitotoksik karena didapatkan nilai $\mathrm{IC}_{50}$ yang lebih kecil dari $100 \mu \mathrm{g} / \mathrm{mL}$ (Prayong et al., 2008).

Nilai selektivitas suatu senyawa bertujuan untuk mengetahui tingkat keamanan suatu senyawa antikanker terhadap sel normal (Ueda et al., 2002). Fraksi dietil eter lebih selektif membunuh sel 
kanker payudara T47D dibandingkan fraksi n-heksana dan etanol. Hal tersebut terlihat dari nilai SI fraksi dietil eter yang tinggi, 8 kali lipat dibanding dengan fraksi n-heksana dan lebih tinggi 3 kali lipat dibandingan fraksi etanol.

Tabel IV. Hasil uji sitotoksik setiap fraksi

\begin{tabular}{cccc}
\hline Fraksi & $\begin{array}{c}\mathbf{I C}_{\mathbf{5 0}} \mathbf{T 4 7 D} \\
(\boldsymbol{\mu} \mathbf{g} / \mathbf{m L})\end{array}$ & $\begin{array}{c}\mathbf{I C}_{\mathbf{5 0}} \text { Vero } \\
(\boldsymbol{\mu g} / \mathbf{m L})\end{array}$ & $\begin{array}{c}\text { Selectivity } \\
\text { index }(\boldsymbol{S I})\end{array}$ \\
\hline n-heksana & $102,75 \pm 0,66$ & $276,88 \pm 1,63$ & 2,70 \\
dietil eter & $10,16 \pm 0,88$ & $254,87 \pm 0,23$ & 25,08 \\
etanol & $56,86 \pm 1,54$ & $318,77 \pm 0,24$ & 5,60 \\
\hline
\end{tabular}

Profil morfologi sel akibat perlakukan fraksi dietil eter diamati. Perlakuan fraksi dietil eter menyebabkan sel T47D mengalami perubahan morfologi yaitu inti sel tampak mengerut, terlihat sel yang mengalami kematian, dan jumlah sel berkurang, sedangkan sel tanpa perlakuan menunjukkan morfologi yang normal (Gambar 4).

Efek sitotoksis fraksi dietil eter terhadap sel Vero berdasarkan nilai $\mathrm{IC}_{50}$ dan profil morfologi sel menunjukkan efek yang lebih rendah jika dibandingkan terhadap sel T47D. Perlakuan fraksi dietil eter juga menyebabkan sel Vero mengalami perubahan morfologi, yaitu sel mengecil, membulat dan tidak lagi menempel pada dasar sumuran, namun diperlukan konsentrasi yang lebih tinggi untuk menghasilkan efek yang sama terhadap sel T47D, sedangkan sel tanpa perlakuan menunjukkan morfologi yang normal (Gambar 5).

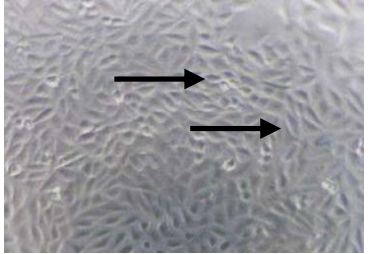

(a)

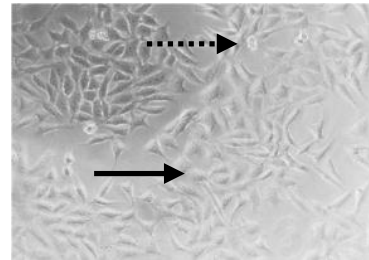

(b)

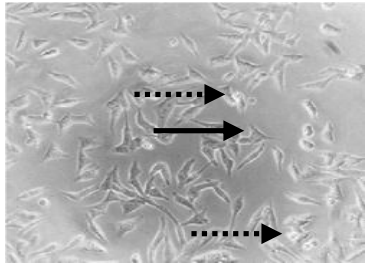

(c)

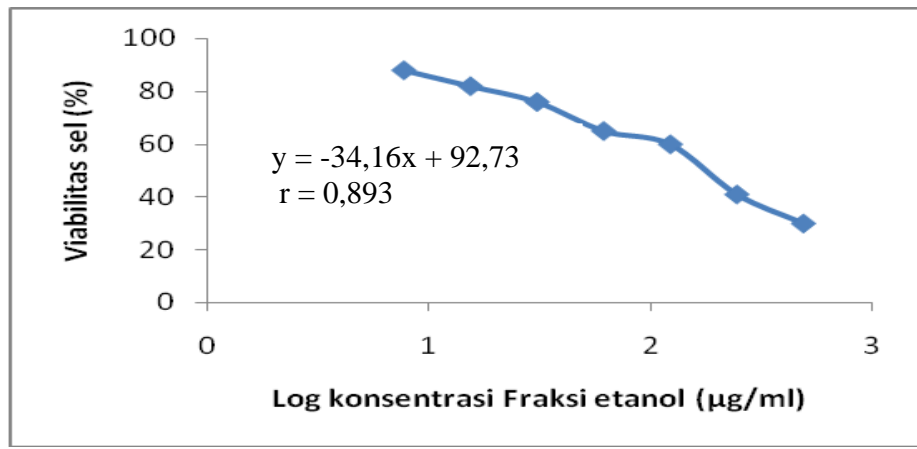

Gambar 4.Efek perlakuan fraksi dietil eter terhadap sel T47D.

Keterangan: Pengamatan dilakukan di bawah mikroskop inverted dengan pembesaran 100x. (a) kontrol sel; (b) Fraksi dietil eter $5 \mu \mathrm{g} / \mathrm{mL}$; (c) $10 \mu \mathrm{g} / \mathrm{mL}$. Morfologi sel T47D yang hidup ditunjukkan dengan gambar panah $(\longrightarrow$ ) dan sel yang mengalami perubahan morfologi ditunjukkan dengan tanda panah putus ( - $>$ ). Nilai $\mathrm{IC}_{50}$ didapatkan dari perhitungan regresi linier log konsentrasi dibandingkan dengan \% viabilitas sel dengan taraf kepercayaan $95 \%(\mathrm{p}<0,05)$. 


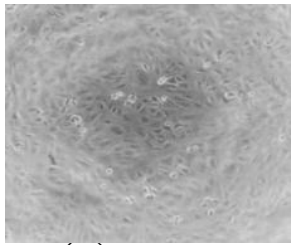

(a)

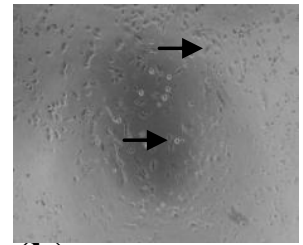

(b)

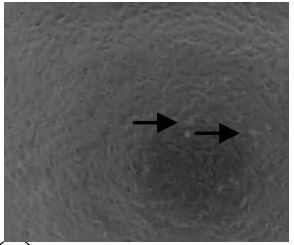

(c)

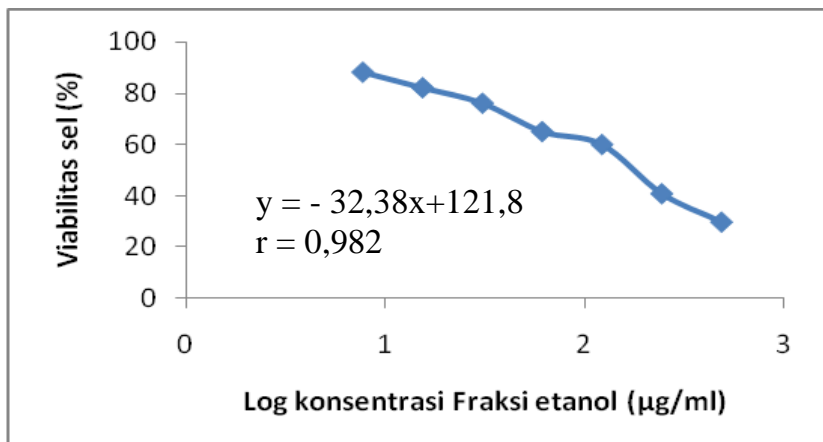

Gambar 5.Efek perlakuan fraksi dietil eter terhadap sel Vero.

Keterangan: Pengamatan dilakukan di bawah mikroskop inverted dengan pembesaran 100x. (a) kontrol sel; (b) Fraksi dietil eter $250 \mu \mathrm{g} / \mathrm{mL}$; (c) $500 \mu \mathrm{g} / \mathrm{mL}$. Perubahan morfologi sel Vero ditunjukkan dengan gambar panah $\longleftrightarrow$ ). Nilai IC $_{50}$ didapatkan dari perhitungan regresi linier log konsentrasi dibandingkan dengan \% viabilitas sel dengan taraf kepercayaan $95 \%$ $(\mathrm{p}<0,05)$.

\section{KESIMPULAN}

Uji aktivitas antibakteri menunjukan bahwa fraksi dietil eter mempunyai aktivitas paling tinggi berdasarkan niai KBM terhadap bakteri uji E.coli, S.aureus, dan S.typhi. Uji kandungan fenolik total menunjukkan bahwa fraksi etanol 96\% mempunyai kandungan fenolik total terbesar dan mempunyai aktivitas antioksidan tertinggi. Uji sitotoksik menunjukkan fraksi dietil eter mempunyai aktivitas sitotoksik tertinggi.

\section{DAFTAR PUSTAKA}

Colpo, E., Vilanova, C.D.D.A., Pereira, R.P., Reetz, L.G.B., Oliveira, L., Farias, I.L.G., Boligon, A.A., Athayde, M.L., Rocha, J.B.T., 2014. Antioxidant effects of Phyllanthus niruri tea on healthy subjects. Asian Pac. J. Trop. Med. 7, 113-118.

Deshmukh, R., Mathew, A., Purohit, H.J., 2014, Characterization of antibacterial activity of bikaverin from Fusarium sp. HKF15. J. Biosci. Bioeng. 117, 443-448. doi:10.1016/j.jbiosc.2013.09.017

Dewoto, R., 2007. Pengembangan obat tradisional Indonesia menjadi fitofarmaka. Majalah Kedokteran Indonesia, 57: 5-6.

Gulcin I. Antioxidant and antiradical activities of L-carnitine. Life Sci 2006, 78(8): 803-811.

Huang,D., Ou,B., Proir,RL. The chemistry behind antioxidant capacity assays. J Agric Food Chem 2005, 53(6): 1841-1856.

Hudziki, J., 2009, Kirby-Bauer Disk Diffusion Susceptibility Test Protocol.

Javanmardi, J., Stusshnoff, C., Locke, E., and Vivanco, J.M., 2003, Antioxidant activity and total phenolic content of Iranian Occimum accessions, J.Food Chem,83, 547-550.

Kharwar, R.N., Verma, V.C., Kumar, A., Gond, S.K., Harper, J.K., Hess, W.M., dkk., 2009, Javanicin, an antibacterial naphthaquinone from an endophytic fungus of neem, Chloridium sp. Current microbiology, 58: 233-238. 
Kumaran, A. dan Karunakaran, R.J., 2007, Activity-guided isolation and identification of free radicalscavenging components from an aqueous extract of Coleus aromaticus. Food Chemistry, 100: 356-361.

Prayong, P., Barusrux, S., and Weerapreeyakul, N., 2008, Cytotoxic activity screening of some indigenous Thai plants. Fitoterapia,79: 598-601.

Sharma, O.P., 1989, Textbook of Fungi. Tata McGraw-Hill Education.

Strobel, G.A., 2003. Endophytes as sources of bioactive products. Microbes and infection / Institut Pasteur, 5: 535-544.

Tan, R.X. dan Zou, W.X., 2001, Endophytes: a rich source of functional metabolites. Natural product reports, 18: 448-459.

Ueda, J.Y., Tezuka, Y., Banskota, A.H., Tran, Q.L., Hariyana, Y., Saiki, I., dkk., 2002, Antiproliferative Activity of Vietnamase Medical Plants. Biol.Pharm, Bull, 25: 753-760.

Zellagui, A., Gherraf, N., Ladjel, S., dan Hameurlaine, S., 2012. Chemical composition and antibacterial activity of the essential oils from Launaea resedifolia L. Organic and Medicinal Chemistry Letters, 2: 2. 